This item was submitted to Loughborough's Research Repository by the author.

Items in Figshare are protected by copyright, with all rights reserved, unless otherwise indicated.

\title{
Developing a critical realist positional approach to intersectionality
}

PLEASE CITE THE PUBLISHED VERSION

http://dx.doi.org/10.1179/1476743014Z.00000000043

\section{PUBLISHER}

(c) W. S. Maney \& Son Ltd

\section{VERSION}

VoR (Version of Record)

\section{PUBLISHER STATEMENT}

This work is made available according to the conditions of the Creative Commons Attribution-NonCommercialNoDerivatives 4.0 International (CC BY-NC-ND 4.0) licence. Full details of this licence are available at: https://creativecommons.org/licenses/by-nc-nd/4.0/

\section{LICENCE}

CC BY-NC-ND 4.0

\section{REPOSITORY RECORD}

Dy, Angela Martinez, Lee Martin, and Susan Marlow. 2019. "Developing a Critical Realist Positional Approach to Intersectionality". figshare. https://hdl.handle.net/2134/19415. 


\title{
Developing a Critical Realist Positional Approach to Intersectionality
}

\author{
ANGELA MARTINEZ DY \\ University of Nottingham \\ LEE MARTIN \\ University of Nottingham \\ SUSAN MARLOW \\ University of Nottingham
}

This article identifies philosophical tensions and limitations within contemporary intersectionality theory which, it will be argued, have hindered its ability to explain how positioning in multiple social categories can affect life chances and influence the reproduction of inequality. We draw upon critical realism to propose an augmented conceptual framework and novel methodological approach that offers the potential to move beyond these debates, so as to better enable intersectionality to provide causal explanatory accounts of the 'lived experiences' of social privilege and disadvantage.

KEYWORDS critical realism, critique, feminism, intersectionality, methodology, ontology

\section{Introduction}

Intersectionality has emerged over the past thirty years as an interdisciplinary approach to analyzing the concurrent impacts of social structures, with a focus on theorizing how belonging to multiple exclusionary social categories can influence political access and equality. ${ }^{1}$ It conceptualizes the interaction of categories of difference such as gender, race and class at many levels, including individual experience, social practices, institutions and ideologies, and frames the outcomes of these interactions in terms of the distribution and allocation of power. ${ }^{2}$ As a form of social critique originally rooted in black feminism, ${ }^{3}$ intersectionality is described by Jennifer Nash as 'outsider knowledge' that has 'transversed disciplinary borders and gained institutional legitimacy'. ${ }^{4}$ Eventually adopted into mainstream feminist discourse, intersectionality is now acknowledged as a significant contribution to feminist scholarship.

However, the scholarly discourse underpinning intersectionality encompasses a range of philosophical, methodological and practical positions that differ greatly in their approaches to analyzing the varying impacts of categories, ${ }^{5}$ and indeed, in their stances on whether this is even possible. Although it is generally accepted that understanding intersectionality helps make visible the influences of multiple categories of oppression, when researchers have attempted to tease out

\footnotetext{
${ }^{1}$ Hancock 2007.

2 Davis 2008, 67-68; Hurtado 1989.

${ }^{3}$ Dhamoon 2011; e.g. Combahee River Collective 1977; Crenshaw 1989; Davis 1981; Hill Collins 1990; hooks 1981.

${ }^{4}$ Nash 2011, 446-447; see also Oleksy 2011.

${ }^{5}$ Davis 2008.
} 
the related forces involved, their approaches have been problematized and their methods critiqued. The inconsistency amongst approaches combined with lack of ontological discussion has led some to suggest that the widespread uptake of intersectionality in feminist theory may be obscuring relevant debates within the field, such as those between liberal, poststructuralist, and black standpoint perspectives. ${ }^{6}$ Additionally, due to its original aim of analyzing the impacts of intersecting forces of oppression, both theory and research have tended to pay less attention to questions of agency and privilege. ${ }^{7}$ Together, these issues have precipitated something of a methodological crisis for intersectionality.

One conceptual approach that has been heavily problematized is the idea that the intersections of certain categories affect identities in a fixed or static way. In response, a more fluid notion of social positionality has been put forward. Positionality builds upon the importance intersectionality places on multiple identities, but concentrates instead on broader social locations and processes that are context-, meaning-, and time-specific, explicitly located within social hierarchies, and tied to both material and cultural resource distribution. ${ }^{8}$ The move towards positionality is clearly articulated by Floya Anthias, for whom intersectionality is a social process of practices and arrangements giving rise to particular forms of positionality, which tend to involve shifts and contradictions. ${ }^{9}$ She suggests that from a temporal view, positionality encompasses both the present outcome of intersectionality - i.e. the being - as well as the process of development that is continually occurring, or the becoming. Like intersectionality, positionality is held to have present effects, yet also be dynamic and subject to changing social and individual circumstances. But in its acknowledgement of potential contradictions, positionality is arguably better equipped than its precursor to articulate discussions of agency and privilege as well as oppression and disadvantage.

There is now a rich history informing intersectionality and positionality theorizing and research, yet the literature rarely calls into question the underlying assumptions that have led to such disparate approaches and methodological rifts. Whilst there have been significant contributions made in identifying and categorizing intersectional approaches, ${ }^{10}$ the various philosophical underpinnings of these approaches are not often clearly elucidated, nor are the effects of their foundations subject to critique. ${ }^{11}$ Thus this article will draw upon the philosophy of critical realism to explore some of the philosophical roots of intersectionality theory and argue that key ontological and epistemological assumptions across the various approaches have led intersectionality into its present crisis of method. We suggest that a number of current limitations can be overcome if critical realism is used to inform theory development. To make this argument, the article is structured as follows. First, contemporary reviews and critiques of intersectionality are examined. Second, the theoretical limitations identified are mapped to implicit roots in positivist and hermeneutic philosophical traditions and the methodological problems engendered by such assumptions articulated. Finally, we propose an outline of a critical realist approach to intersectionality that addresses how these problems can be reconciled, and in so doing, offer an alternative philosophical foundation for future intersectional research.

\footnotetext{
${ }^{6}$ Carbin \& Edinheim 2013.

${ }^{7}$ Nash 2008.

${ }^{8}$ Anthias 2001 a\&b, 2002, 2006, 2008.

${ }^{9}$ Anthias 2008.

${ }^{10}$ McCall 2005; Mehrotra 2010.

${ }^{11}$ Carbin \& Edinheim 2013.
} 


\section{Intersectional complexity and the limitations of current approaches}

Because of ambiguity in basic definitions and the complexity of the subjectivities with which it grapples, there is a notable lack of consensus about key elements of intersectionality theory. A case in point concerns inconsistency in conceptualization: depending on the author or context, intersectionality has been considered a theory, a paradigm, a framework, a method, a perspective, or a lens. ${ }^{12}$ Such vagueness and ambiguity has been both heralded for its flexibility and usefulness ${ }^{13}$ as well as identified as a central tension within the literature ${ }^{14}$ There is also a conspicuous dearth of explicit ontological and epistemological discussions within the field. ${ }^{15}$ Combined, these issues have meant there is currently a limited range of methodological tools with which to research intersectionality, leading to the conclusion that intersectionality is methodologically undertheorized. $^{16}$

One exception is found in Leslie McCall's work. Defining methodology as encompassing the philosophy and methods that underpin the research process and production of knowledge, she identifies three distinct methodological strands within intersectional research: anti-categorical complexity, intra-categorical complexity, and inter-categorical complexity. ${ }^{17}$ Anti-categorical approaches attempt to deconstruct and reject analytical categories, starting from the assumption that categories, including race and gender, are too simplistic to capture the complexity of lived experience. ${ }^{18}$ Intra-categorical approaches, representative of the original approach of intersectionality, attempt to focus on social groups at neglected points of intersection. Intercategorical approaches, described as the 'strategic use' of categories, 'begins with the observation that there are relationships of inequality among already constituted social groups, as imperfect and ever changing as they are, and takes those relationships as the centre of the analysis. ${ }^{19}$ McCall notes that not all research on intersectionality can be categorized into one of the three types of approaches, that some will cross categorical boundaries, that there may not be homogeneity within the categories, and that she may have misunderstood or misclassified some pieces of research. ${ }^{20}$ However, the methodological strands she describes provide a useful framework for analyzing extant intersectional methodology, particularly because the framework presented does not reflect upon the ontological and epistemological underpinnings of intersectional research. It will be later argued that the current limitations of intersectional theory correspond to problematic ontological and epistemological assumptions underpinning the various types of approaches outlined by McCall.

\section{Positivism in intersectionality theory}

Positivism is a philosophy of science that underpins much of the natural sciences. There are many forms of positivist thought, but some of the most influential forms were developed from the work of Comte and Hume. For Hume, causality was synonymous with regularity between events, i.e. if

\footnotetext{
12 Mehrotra 2010.

${ }^{13}$ Davis 2008, 76.

${ }^{14}$ Nash 2008.

${ }^{15}$ Carbin \& Edinheim 2013.

${ }^{16}$ Bowleg 2008; McCall 2005.

${ }^{17}$ McCall 2005.

18 Nash 2008; c.f. McCall 2005.

${ }^{19}$ McCall 2005, 1784-1785.

${ }^{20}$ McCall 2005, 1774.
} 
event $x$ and event $y$ are regularly conjoined, it is presumed that one causes the other. His philosophy of science, therefore, emphasizes the importance of empirical observation for uncovering such causal laws, and that knowledge claims about the natural world should be limited to such uncovered events. Roy Bhaskar recognized that this set of ideas and the principles of the related philosophy of empiricism contained the implicit ontological assumption that reality is limited to that which is observable and measurable. He termed this the epistemic fallacy: what we consider real is limited to what we can know. ${ }^{21}$

Feminist theory has also critiqued dominant philosophical frameworks; in particular, for their privileging of men and lack of grounding in women's experiences. ${ }^{22}$ It has challenged the forms of positivism described above for their insistence on the primacy of masculinist empirical observation for the construction of knowledge. ${ }^{23}$ Multiple feminist interdisciplinary methodological approaches have thus been developed, including feminist empiricism, standpoint theory and postmodern perspectives, some of which have themselves been critiqued for similar exclusionary limitations. ${ }^{24}$ Intersectionality as a diverse and pluralist paradigm has drawn and built upon all of these, with particular grounding in structuralist standpoint feminism. ${ }^{25}$ And whilst its philosophical underpinnings have not tended to be at the forefront of the conversation, McCall notes that those in anti-categorical and intra-categorical camps tend to associate advanced quantitative techniques, large data sets, and surveys with the negative legacies of positivism. ${ }^{26}$ However, whilst intersectionality has clearly been influenced by both feminist standpoint theory and postmodern perspectives, it will be argued that the positivist and feminist empiricist traditions have had a larger impact upon intersectional theory building than has been previously acknowledged.

Some of the inter- and intra-categorical intersectional approaches identified by McCall seem to contain implicit positivist assumptions as they attempt to theorize the nature and kind of causes at work in structures of domination, as well as to articulate the historically specific conditions under which they exist. The concern with identifying such causes means that some of this research has treated categories such as race and class as discrete and separable. Subsequently, race, class and gender have been portrayed and analyzed as fixed categories with discrete, consistent and measurable effects ${ }^{27}$ when they are in fact 'shifting, slippery, [and] highly contextual'. ${ }^{28}$ This is an issue within identity-centred intersectionality scholarship in general, as identity - and by extension, difference and inequality - may be treated as static and possessive attributes of individuals or groups. ${ }^{29}$ Gita Mehrotra points to the predominance of mathematical and geometric metaphors invoked to structurally describe intersectionality, including vectors of difference, matrices of oppression, and axes of power, ${ }^{30}$ along with the problematic additive model, and its cousin, the multiplicative model. ${ }^{31}$ These metaphors suggest that gender, race, and class can be considered

\footnotetext{
${ }^{21}$ Bhaskar [1979] 1998.

22 Harding 1986.

${ }^{23}$ McCall 2005.

${ }^{24}$ Harding, 1986; 1991; Letherby, 2003; New, 1998.

${ }^{25}$ Carbin \& Edenheim 2013.

${ }^{26}$ McCall 2005, 1791.

${ }^{27}$ Mehrotra 2010; Nash 2011.

${ }^{28}$ Nash 2011, 461.

${ }^{29}$ Anthias 2006; 2008.

${ }^{30}$ Mehrotra 2010, 420-421.

${ }^{31}$ Nash 2008, 7.
} 
separately and so, understood and analyzed through, for example, additive calculation. ${ }^{32}$ The extensive use of mathematical tropes to portray structural conditions is clearly reflective of a positivist legacy and has created a conceptual cul-de-sac that makes it difficult to imagine other ways in which structures might interact.

Additionally, Hume's philosophy of science informed positivist methodologies that suggest hypothesis development and the prediction of the results of empirical investigation are important to knowledge formation. Tendencies towards prediction are arguably at the root of why simplistic quasi-predictive conceptualizations, such as the additive approach, wherein experiences of oppression explained in terms of the sum total of the oppressions of the relevant marginalized categories, became popular. Such conceptualizations, however, have now been roundly critiqued as both unlikely and essentializing. ${ }^{33}$ Ironically, it was just this kind of quasi-predictive approach that was specifically challenged in seminal intersectional work, which served to complicate essentialist notions of womanhood espoused by second wave feminism through challenging the assumption that categories such as 'woman' or 'black' affect everyone within their bounds in a similar manner, whilst taking the assumed stability of those boundaries to task. For example, Patricia Hill Collins stressed that common challenges did not necessarily produce common experiences. ${ }^{34}$ But Nash notes that early theorists' work on the intersections of race and gender in particular, pushed these two constructs to the fore, and away from grappling with other issues of multiple marginality. The legacy of this early work is still present: Nash points out that intersectional projects often replicate precisely the approaches that they critique ${ }^{35}$ by reifying categories or overlooking heterogeneity due to bracketing or ignoring categories with which they are not explicitly concerned.

Black feminist critiques of theory as elitist and exclusionary ${ }^{36}$ were concordant with other feminist critiques of the androcentric construction of 'knowledge' in the natural sciences, which pointed out that a science created by Western, bourgeois, white heterosexual men can only be subjective. ${ }^{37}$ Despite these critiques, intersectional scholars have yet to address the epistemic fallacy ${ }^{38}$ within their epistemologies. In their attempt to contest the idea of theory as neutral, Nash points out that the black feminist scholarship in which intersectionality is grounded intentionally 'collaps[ed] the distinction between theory and experience'. ${ }^{39}$ Yet, in spite of such justifiable intentions, it still results in problems of being becoming conflated with problems of knowing. Thus, the conflation of experience, theory, and knowledge that feminism critiqued in the scientific tradition can be seen to have been replicated within this category of intersectionality theory, albeit with important differences; the vantage point was now articulated and embodied. It was no longer elite, but instead occupied a subjugated position in the social hierarchy. As such, from the perspective of feminist standpoint theory, it had the potential to precipitate an acute awareness of relationships of power, described by Donna Haraway as 'vision...from below'. ${ }^{40}$ Although there is undeniable value in the demarginalization of subjugated worldviews, intersectional theories suffer from the epistemic fallacy when they do not separate ontological claims from their epistemological

\footnotetext{
32 Mehrotra 2010, 421.

33 E.g. Bowleg 2008; Hancock 2007; Yuval-Davis 2006.

${ }^{34}$ Hill Collins, 1990/2000

${ }^{35}$ Nash 2011; 2008, 6.

${ }^{36}$ E.g. Hill Collins 1990.

37 E.g. Haraway 1988; Harding 1986, 1991.

${ }^{38}$ Bhaskar [1979] 1998, 133; [1975] 2008, 13, 36.

${ }^{39}$ Nash 2011, 462-3.

${ }^{40}$ Haraway 1988, 583.
} 
origins. As a result of this philosophical legacy, intersectionality scholarship risks omitting from its theories that which may be unexercised, unactualized, or unobserved; this will be explored in more detail later.

\section{The hermeneutic tradition and intersectional identity}

Hermeneutics has its origins in ancient Greek philosophy, although modern hermeneutics is derived from many thinkers, such as Heidegger, Gadamer and Habermas. Whilst there is heterogeneity in these approaches, what links them is a focus on meaning via textual interpretation or sensemaking. Phenomenology, the study of the structures of experience, and constructivism, the argument that all knowledge is a social construction, are derived, in some way, from this hermeneutic tradition, whilst poststructuralism can be considered part of its radical intellectual evolution. Like phenomenology, poststructuralism is primarily concerned with how people experience and make sense of the world and warns against research that seeks to uncover underlying truths. ${ }^{41}$ What makes it radical is the basic premise that it is fundamentally impossible to accurately represent the world. ${ }^{42}$ Although differences between authors are acknowledged, for the purpose of this article, these schools of thought will be subsumed under the umbrella of the hermeneutic tradition. Contemporary work on intersectionality is predominantly associated with the anti-categorical approaches identified by McCall, which, taking broadly defined hermeneutic (predominantly constructivist and poststructural) positions, tend to view categories as 'simplifying social fictions, ${ }^{43}$ based upon the idea that social reality is a fluid and co-constitutive phenomenon that cannot be depicted in simplistic, categorical and discrete ways. ${ }^{44}$ Within such intersectionality research, these approaches have helped to further complicate notions of categories of belonging, highlighting their political function. However, the retained focus on interpretation, due to what is perceived to be the impossibility of truth claims, carries the risk that such research will be 'drained of causal import ${ }^{\prime 45}$ as it attends primarily to individual interpretations of reality.

Importantly, neither hermeneuticist nor positivist traditions articulate an ontology that includes a notion of transfactuality, i.e. that causes can exist and endure without our knowledge of them. For Bhaskar, the lack of an articulated ontology concerning causality results in the tacit adoption of an implicit one. Critiquing the hermeneutic tradition for the way it regards the key problems of philosophy arising from the 'conditions, limits and forms' of language ${ }^{46}$ he argues that the consequence of the implicit ontological assumptions within the hermeneutic tradition is that society is entirely conceptual in character, with its central category being that of meaning. ${ }^{47}$ Although prominent poststructuralists such as Judith Butler have argued that categories are still relevant and that hegemonic discourses do have significant material consequences, ${ }^{48}$ the problematic methodological implication of this line of thinking when translating these abstract arguments to research is that structural issues tend to be analyzed primarily in terms of individual

\footnotetext{
${ }^{41}$ Brown \& Heggs 2005

${ }^{42}$ Carbin \& Edenheim 2013.

${ }^{43}$ McCall 2005, 1773.

${ }^{44}$ Mehrotra 2010, 421.

${ }^{45}$ Bhaskar [1979] 1998, 12.

${ }^{46}$ Bhaskar [1979] 1998, 133.

${ }^{47}$ Bhaskar [1979] 1998, 133-5.

${ }^{48}$ Butler 1990, 1998.
} 
experiences and related understanding of them, to the detriment of the analysis of unrecognized structural impediments ${ }^{49}$ and their relationship with individual agency. ${ }^{50}$

The tendency of anti-categorical intersectionality theorists to focus ever more closely on the meaning-making processes of the individual reflects the methodological restriction imposed through this tradition. Within anti-categorical discourse, notions of positionality or structural discrimination are often collapsed into the concept of 'identity'. Yuval-Davis defines identities as individual and collective narratives that answer questions of who we are. She notes, however, that in contemporary literature, concepts of identity are often required to perform analytical tasks beyond their abilities. ${ }^{51}$ For example, the study of identity at the level of the individual seems illsuited to providing wider contextual analysis for a given social condition. Although exploring identity can provide insight into how people perceive, make sense of and cope with particular circumstances, it cannot speak decisively about how structural components of those circumstances may be determined by the wider social field. The predominance of inquiries into intersectional identity is herein argued to be a continuation of the hermeneutic focus on the discursive construction of reality as it manifests at the micro level. Concurrently, there is a conspicuous lack of theory on the intersecting structural conditions that engender these realities, ${ }^{52}$ in which resource inequalities of various kinds produce complex experiences of discrimination and privilege. ${ }^{53}$ This poses significant challenges for intersectional scholars seeking to explain macro-level conditions without contradicting their philosophical tradition.

Table 1 shows the three existing approaches to intersectional methodological complexity. ${ }^{54}$ Drawing upon critical realist perspectives, ${ }^{55}$ it illustrates how these approaches are implicitly informed by the positivist and/or hermeneutic traditions, and highlights some of the common problematic outcomes that occur as a result.

\section{TABLE 1 ABOUT HERE}

Whilst many poststructuralist scholars have embraced intersectionality and vice versa, Maria Carbin and Sara Edenheim have critiqued intersectionality's apparent hegemony within current feminist theory, arguing that there is no room in the field of intersectionality for a poststructuralism based on the premise that reality is inherently unknowable, and which does not share the 'dream of a common feminist language. ${ }^{56}$ They lend temporal and political context to the debate when they argue that intersectionality's widespread adoption into feminist theory, constructivist intersectionality especially, has come to signal a 'liberal consensus-based project...in an increasingly neoliberal and conservative European context. ${ }^{, 57}$ Intersectionality has also been challenged by

\footnotetext{
${ }^{49}$ Yuval-Davis 2006.

${ }^{50}$ Clegg 2006; see also Carbin \& Edinheim 2013.

${ }^{51}$ Yuval-Davis 2006.

${ }^{52}$ Acker 2000, 2006; Yuval-Davis 2006.

${ }^{53}$ Anthias 2001; Nash 2011.

54 McCall 2005; Mehrotra 2011; Nash 2008.

${ }^{55}$ Bhaskar 1998; Gunnarsson 2011.

${ }^{56}$ Carbin \& Edinheim 2013, 232.

${ }^{57}$ Carbin \& Edinheim 2013, 245.
} 
feminist new materialists Evelien Geerts and Iris van der Tuin, who critique what they see as its denial of agency and, addressing the gap around intersectional ontology, follow Karen Barad in arguing for an explicit onto-epistemology, or 'entanglement' between being and knowing. ${ }^{58}$ Thus, it is both useful and timely to introduce the concepts of critical realism to intersectionality theory. A philosophy of science that accepts the transfactual existence of causal powers emerging from structural categories and positions, and which explains how agency interacts with, reproduces, and changes these structures, offers the opportunity to strengthen intersectionality's philosophical underpinnings and move beyond these restricting debates.

\section{Towards a critical realist intersectionality}

Critical realism can help address the limitations of existing intersectionality theory by providing an alternative ontology and epistemology to those that currently predominate. The critical realist philosophy contains a conception of causality that enables an understanding of how the social world can exist independently from our knowledge of it. Bhaskar's philosophy of science arose from asking the question: What must the world be like in order for science, as we understand it, to be possible? Arguing that because it is possible to identify correlations and causation through experimental activity, his conclusion was there must be underlying causal mechanisms enabling such events to be measured. Because these correlations may not endure outside of this experimental activity (as they require scientific work in order to be identified) the causal mechanisms that lead to them must be considered separate from the events they generate. In other words, causes have essential properties that operate continuously, regardless of any immediate effect. ${ }^{59}$ Bhaskar then proposed that these causal mechanisms underpin events, and that mechanisms can be considered real if they 'have an effect or make a difference'. ${ }^{60}$ This logic enabled the conclusion that the social world must be stratified into at least three domains: the empirical, in which events are observed and measured; the actual, in which events occur irrespective of our knowledge of them; and the real or the deep, where causal powers can be exercised (formed but not necessarily acting) or un-exercised (yet to be formed but possible given current conditions). ${ }^{61}$

Whilst acknowledging important contributions to knowledge from both positivist and hermeneutic traditions, Bhaskar points out two fundamental oversights. First, both strands of thought predicate a flat and positive ontology, which he terms 'ontological monovalence' ${ }^{62}$ Here both philosophies make implicit assumptions that there can be no absence, and no potential, in the world. Positivism assumes only that which can be measured exists; hence, the unobserved cannot be considered part of reality. The hermeneutic tradition implicitly assumes that if something is not registered within the subjective perception or sense-making processes of an individual we can make no claim to knowing it, and by consequence it cannot be considered part of the social world. This again restricts what can be theorized about the unsaid, the unknown, the absent and what may lie in potential. Second, he identified that neither philosophical approach allows for the possibility of transfactuality: the idea that causal powers can exist without being actualized in

\footnotetext{
${ }^{58}$ Geerts \& van der Tuin, 2013.

${ }^{59}$ Bhaskar [1975] 2008.

${ }^{60}$ Fleetwood 2004, 29.

${ }^{61}$ Mole 2012; cf. Bhaskar [1975] 2008.

${ }^{62}$ Bhaskar [1993] 2008.
} 
events or recognized by observers. ${ }^{63}$ Instead, only causes or mechanisms that are observed, experienced and measured are acknowledged, with no means of accounting for that which may not be actualized or recognized. Thus, according to both traditions, any social cause or mechanism that is either unactualized or unrecognized by actors cannot be assumed to exist. Bhaskar proposes transfactuality as a path through this divide, in which causal mechanisms are considered real and external to individuals, but transcendentally so. Accordingly, they may exist actualized or unactualized, perceived or unperceived. The possibility of knowing their existence is pursued through the development of fallible theories, including that of their potential transfactuality.

This logic provides a means with which to reconcile some key problems facing current intersectionality theory. For example, there is a tendency within intersectionality theory to avoid conceptualizing privilege. ${ }^{64}$ This means theory has not clearly articulated ways in which individuals may be subject to oppression by certain mechanisms whilst benefiting from privilege because of others. Nash articulates this need when she comments that 'progressive scholarship requires a nuanced conception of identity that recognizes the ways in which positions of dominance and subordination work in complex and intersecting ways to constitute subject experiences of personhood'. ${ }^{65}$ This could be addressed by incorporating a notion of transfactuality into intersectionality's conceptualization of complexity. Transfactuality enables the conceptualization of causal mechanisms emerging from the level of society that in some cases are unactualized or unrecognized and yet, which are still held to function. For example, it is particularly useful for theorizing privilege, since the ways it is normalized and made to seem natural ${ }^{66}$ mean that it tends to go unacknowledged and unrecognized, particularly by those whom it benefits. ${ }^{67}$ Thus, it is entirely possible and likely quite common that someone could believe they are not privileged on the basis of their normative race, dominant gender, or higher social class, and for this belief to be incorrect. Another way of conceptualizing privilege could utilize the critical realist notion of absence; ${ }^{68}$ in this case, privilege could mean the absence of additional obstacles to success as a result of belonging to the dominant race, class, or gender. These concepts would be especially useful for enabling intersectionality theory to explain how individuals may be subject to oppression in some ways but privileged in others.

In another example, an institution or organization may have an implicit culture of sexism and racism in relation to career progression and the allocation of financial rewards, yet these mechanisms may not be perceived by those benefiting from them, and unacknowledged by those perpetuating them. However, the transfactuality of mechanisms of privilege and discrimination means that they operate whether or not they are acknowledged to exist. It also explains why, within the same organization, individual women and people of colour might advance, but the demographic composition of the management structure remains predominantly white and male. Though the overall tendency of the structure is governed by the dominant mechanisms of sexism and racism, discriminatory mechanisms may not be actualized in all cases, and other mechanisms say, a corporate call for diversity or an equal opportunities policy - may potentially provide some countervailing forces. Incorporating the concepts of transfactuality and absence in this way can

\footnotetext{
${ }^{63}$ Bhaskar [1979] 1998; [1975] 2008.

${ }^{64}$ Nash 2008.

${ }^{65}$ Nash 2008, 10.

${ }^{66}$ Maier 1997; Mclntosh 1989.

${ }^{67}$ Frankenberg 1993; Ahmed 2012.

${ }^{68}$ Bhaskar [1993] 2008.
} 
help advance intersectional theory at both the micro- and macro-levels, in order to more accurately theorize the nature of systems of oppression and privilege.

\section{Critical realist feminism in an intersectional framework}

Although critical realism has seen only initial deployment within feminist theory in general ${ }^{69}$ and intersectionality theory in particular, ${ }^{70}$ critical realist feminists such as Lena Gunnarsson and Caroline New have responded to the poststructuralist and anti-categorical approaches that feature prominently in intersectional literature. Gunnarsson notes that as a result of these approaches, the category 'woman' is now assumed to have little positive theoretical validity in feminist literature. ${ }^{71}$ This is corroborated by McCall, who observes that anti-categoricalism has led to 'great scepticism about the possibility of using categories in anything but a simplistic way', and highlights the potential value of critical realism to intersectionality theory. ${ }^{72}$ Gunnarsson explains that the rejection of the category 'woman' stems from 'deny[ing] categories any analytical validity by virtue of their empirical inseparability'; ${ }^{73}$ however, she maintains that it is not impossible to distinguish gender analytically from other categories. Indeed, she argues that an intersectional standpoint is premised upon a category called 'gender' being analyzed in conjunction with other categories. But for anti-categoricalists, notes McCall, 'the notion that gender is constructed entails that it is a fiction' ${ }^{74}$ In contrast, critical realist feminists maintain that women are a real group, joined by the abstract social category of 'woman', ${ }^{75}$ who, New argues, may have some universal interests despite the reality of heterogeneity. ${ }^{76}$ So, although categories like race, ethnicity and gender are understood to be constructions, and as such are not based on embodied reality or any 'essential truth' about a group, this does not negate the fact that they have significant social meaning.

Gunnarsson details a realist understanding of categories such as race/ethnicity, class and gender as neither essential nor analytically inseparable, but instead as abstractions with real social, political, cultural and economic implications within their respective contexts. Categories are seen to have real material and social effects, particularly on what Anthias refers to as the 'set of outcomes relating to life conditions, life chances and solidarity processes' ${ }^{77}$ They serve to enable or constrain opportunities, resources, perception by self and others, and treatment in social settings. However, the usefulness of even abstract categories is still under debate within critical realist feminism; SylviaWalby et al. argue for a move away from concepts such as 'category' that connote unity, and toward phrases like 'regimes' or 'set of unequal social relations'. ${ }^{78}$ Thus, any critical realist understanding of categories as abstractions 'implies neither essentialism nor homogenization ${ }^{79}$ of the people to whom the categories refer. Instead, it is the social meanings that categories convey,

\footnotetext{
${ }^{69}$ E.g. Clegg 2006.

${ }^{70}$ E.g. Walby et al. 2012.

${ }^{71}$ Gunnarsson 2011.

72 McCall 2005, 1773.

73 Gunnarsson 2011, 26.

${ }^{74}$ Gunnarsson 2011, 29, original emphasis.

${ }^{75}$ Gunnarsson 2011.

${ }^{76}$ New 2003.

${ }^{77}$ Anthias 2001, 367.

${ }^{78}$ Walby et al. 2012, 230, 236.

${ }^{79}$ Gunnarsson 2011, 24.
} 
and the structural positions to which they correspond, that lead to such essentializing perceptions, resulting in treatment that reproduces or exacerbates inequalities in social conditions.

Finally, Bhaskar's notion of concrete universality ${ }^{80}$ provides the necessary theoretical links between the category-as-abstraction and heterogeneous individual experiences. He describes abstract universal categories (e.g. woman) as being mediated by intersecting factors (including race, class, age, sexual orientation, ability, etc.) and framed in a particular geopolitical and historical context. This, combined with the irreducible uniqueness of individuals, defines the concept of a concrete universal, in which abstract categorical belonging is held to be located in a particular spatial/temporal context, mediated by social positionality, and concretized in the life experiences of individuals. It enables elaboration upon critical realist feminist perspectives on the validity of the category 'woman' ${ }^{81}$ whilst at the same time preserving important intersectional critiques of categorical essentialism by articulating the key factors that produce heterogeneity of experience, therefore, broadening the understanding of what a 'universal' category is able to encompass.

\section{Structure and agency in intersectional theory}

The lack of a well-defined relationship between structure and agency, as well as between structures themselves, are further hurdles within intersectional theory that a critical realist approach could help to clarify. It may be the case that since the so-called poststructural turn in feminism, implicit influences from the hermeneutic tradition contributed to the current tendency to avoid theorizing structure within intersectional theory, although a number of pioneering structuralist scholars (e.g. Floya Anthias, Angela Davis, Patricia Hill Collins, bell hooks and Nira Yuval-Davis ${ }^{82}$ ) have made significant contributions in this area. But with the current predominance of anti-categorical approaches, attention has been much more heavily focused on individual interpretations of social reality. The relationship between structure and agency has therefore, been arguably undertheorized as a result, as has the interaction between agency and the replication of the structures of domination, gaps which are highlighted in contemporary critiques of the literature. ${ }^{83}$ Thus far, neither positivist nor poststructuralist approaches have conceptualized this relationship between structure and agency in a way that has been widely adopted by intersectionality theory, leaving one of its key aims unfulfilled: Nash observes that due to the lack of a comprehensive theory of agency, intersectionality theory has thus far been unable to 'answer...questions about the fit between intersectionality and lived experience of identity'. ${ }^{84}$

Conceptualizing structure and agency, and the relationship between them, is a widely contested area of social theory, ${ }^{85}$ replete with vigorous debate that due to limitations of space it is not possible to engage with here. For now, however, we turn to realist sociologist Margaret Archer's conceptions of structure and agency, as they are rooted in critical realism and contain much promise for propelling intersectional theory forward past these intellectual hurdles. In Archer's model, termed the morphogenetic approach, structures are regarded as products of past human agency, influencing actors in the present who can then contribute to either the

\footnotetext{
${ }^{80}$ Bhaskar [1993] 2008.

${ }^{81}$ Gunnarsson 2011; New 2003.

82 Anthias \& Yuval-Davis 1992; Davis, 1981; Hill Collins [1990] 2000; hooks 1981.

${ }^{83}$ McCall 2005; Nash 2008; Yuval-Davis 2006.

${ }^{84}$ Nash 2008, 11.

${ }^{85}$ Archer 1995; Bhaskar [1979] 1998; Bordieu 1977; Butler 1990; Giddens 1979; McNay 2000.
} 
reproduction or transformation of these pre-existing structures. The influence of structure upon actors is two-pronged. First, structure is held to affect life-chances, endowing them with initial interests and providing the leverage upon which reasons for different courses of action operate. Thus, whilst life chances are not deterministic, they 'strongly condition what type of Social Actor the vast majority can and do become'. ${ }^{86}$ Second, structure is argued to be mediated by social actors primarily through affecting their 'constellation of concerns' in relation to the natural, practical, and social orders of reality. This mediation manifests and takes shape through a process of reflexive internal conversation, which then results in chosen courses of action.

Archer challenges the conflations within contemporary social theory that attribute social phenomena either entirely to the influence of structure (e.g. structuralism) or agency (e.g. rational agent models), or, as in the case of structuration theory, ${ }^{87}$ collapses the two. In response to these deterministic and individualistic approaches, the morphogenetic approach: 'shows (a): how human agency is socially mediated but is irreducible to social norms, and (b) how any account of human agency must include emotional and normative factors as well as any reference to rationality'. ${ }^{88}$ It acknowledges the historicity and objectivity of the circumstances of social structure, its consequent impacts on life-chances and the potential for agential reflexivity and choice within the options available to them. It addresses subjectivity by acknowledging an agent's personal powers, and considers reflexivity, or the internal conversation, to be the primary medium by which the social world is mediated in action. ${ }^{89}$ Although it recognizes social positioning, or the 'differential placement of agents in relation to the distribution of resources,' it highlights 'the impossibility of deducing determinate courses of action from such positionings alone' ${ }^{90}$ It thus rejects both determinism and voluntarism in favour of a dialectical, interactionist and mutually constitutive approach to the explanation of social phenomena. It offers the potential to advance anticategorical approaches to intersectionality, in which discussions of agency tend to be limited to issues surrounding the discursive construction of power. ${ }^{91}$ Instead, this approach centres on and upholds the primacy of practice, a conceptual parallel for the intersectional feminist notion of 'lived experience', which Archer holds 'yields reasoned knowledge nondiscursively' and also 'underlies practical proficiency in the linguistic domain'. ${ }^{92}$

Although the lack of a theory of agency has not prevented researchers from exploring how individuals negotiate intersecting oppressions within their experiences, ${ }^{93}$ critical realist notions of the structure-agency relationship, such as Archer's three-stage model ${ }^{94}$ and morphogenetic approach $^{95}$ can undoubtedly be used to theorize how individuals and groups can be constrained or enabled by structures, and how agency can affect structures in turn. Table 2 summarizes the suggestions offered thus far for how critical realism may usefully be applied to intersectionality. It is not meant to be exhaustive, but is intended as a starting point for identifying some valuable ways in which critical realist philosophy could potentially help to advance the intersectional project.

\footnotetext{
${ }^{86}$ Archer 2000, 285.

${ }^{87}$ Giddens 1979.

${ }^{88}$ Cruickshank 2003, 4.

${ }^{89}$ Archer 2007.

${ }^{90}$ Archer 2007, 13.

${ }^{91}$ New 2003; e.g. Prins 2006

${ }^{92}$ Archer 2000, 151.

${ }^{93}$ E.g. Essers et al., 2010.

${ }^{94}$ Archer 2000.

${ }^{95}$ Archer 1995; 2000.
} 
TABLE 2 ABOUT HERE

\section{Critical realism and a positional approach to methodological complexity}

Having critically examined the current problems and tensions within intersectionality theory, it is now possible to introduce a new methodological approach to inform research and theory building. To overcome existing limitations, a novel methodological approach is necessary and can be achieved through drawing upon the ontological assumptions within critical realism. This approach attempts to rectify the problematic assumptions and outcomes of the three approaches outlined by McCall $^{96}$ by drawing upon critical realist philosophy to sketch a novel intersectional ontological framework. The development of such an approach can reinvigorate intersectionality theory with the ability to assess how a particular individual's social position is enabled and constrained by generative structural mechanisms, and how these mechanisms operate in regard to particular intersections of wider structural categories, such as race, class, and gender. Of the existing approaches, the treatment of social categories has been taken to be their most prominent feature and lent itself to their names. However, the conceptual tools found within critical realism enable us to not only acknowledge the importance of such categories, but also to extend attention beyond them to that of positionality. This new approach will therefore be referred to as the 'positional' approach, presented here as an augmented conceptual framework to existing intersectionality theory. Its key characteristics are outlined in Table 3 below.

\section{TABLE 3 ABOUT HERE}

From a critical realist positional approach, abstract concepts such as 'women' would be acknowledged to be 'qualitatively different from lived reality', and so could be used as categories of analysis 'without any expectation that they will correspond to...lived reality in any clear-cut sense' ${ }^{97}$ Instead, they will correspond to structural positions. Into each of these positions will be built, 'certain structured interests, resources, powers, constraints and predicaments', instituted by the web of relationships that make up a social structure. ${ }^{98}$ The notion of structural positions within critical realism strongly echoes the intersectional notion of positionality. Aligning the two concepts, a positional approach enables the claim that generative structural mechanisms of oppression and privilege can emerge from the durable yet dynamic intersections of social categories. Such mechanisms position agents in particular social locations in which agency, the force by which we negotiate our positioning, is enabled or constrained in relation to the effects of such privilege and oppression on lived experience. Archer's well-elaborated notions of agency ${ }^{99}$ can help to draw

\footnotetext{
${ }^{96}$ McCall 2005.

${ }^{97}$ Gunnarsson 2011, 32.

98 Porpora 1998, 344.

${ }^{99}$ Archer 1995, 2000, 2007.
} 
feminist theorizing away from poststructuralist conceptions of a fragmented, disempowered subject and towards a unified, embodied subject capable of agency ${ }^{100}$ and engaged in processes of social positioning. Accordingly, positionality would be understood to influence life-chances, ${ }^{101}$ concrete access to material, economic, political, symbolic and cultural resources, ${ }^{102}$ and condition the cognitive resources available for conducting the internal conversations, both conscious and unconscious, that influence agent action. ${ }^{103}$

A critical realist intersectional ontology, as shown in Table 4, accounts for the various structural forces privileging and disadvantaging individuals, even if events expected to arise from them did not occur or were not recognized (transfactuality). These forces would be understood to be emergent; as such, they adhere to the critical realist conception of emergence ${ }^{104}$ in which reality is arranged in levels, and something qualitatively new can emerge from a lower level. ${ }^{105}$ Some key examples of mechanisms emergent from the level of society are racism (discrimination for not belonging to the dominant race), sexism (discrimination for not belonging to the dominant gender or refusing the prescriptions of one's assumed gender), and classism (discrimination for not belonging to the dominant class). Emergence also means that new forces can arise from the historical interactions of other mechanisms. The notion of misogynoir, defined as the hatred of black women and girls, ${ }^{106}$ is an example of such a mechanism, structurally emergent from the interactions of racism and sexism. A realist intersectional ontology would illuminate how, although social categories may be abstract constructions, they serve to define real relationships of power from which causal mechanisms emerge. Moreover, these mechanisms can in some cases exist unactualized, or be actualized but unrecognized by actors, groups and institutions. Subsequently, research can identify how intersectional forces are perceived (or not) by individual agents and wider social structures. This opens research methodology to explore intersectional forces on the three levels of reality Bhaskar identified, as well as the emergent levels within them. ${ }^{107}$

\section{TABLE 4 ABOUT HERE}

This article has argued that intersectionality has thus far been shaped predominantly by philosophical roots in positivist and hermeneuticist perspectives. From a positivist perspective, prediction is desired, categories are treated as fixed and their intersections conceptualized as separable and calculable. ${ }^{108}$ From a hermeneuticist perspective, social categories are to be deconstructed and rejected, and what is instead sought is 'the constitution of subjectivity within discourse ${ }^{\prime 109}$ with a focus on identity as metonym for how this subjectivity is constructed. In contrast, a critical realist perspective would distinguish between theory and experience, analytically

\footnotetext{
100 Clegg 2006.

${ }^{101}$ Archer 2000; Anthias 2001b.

102 Anthias 2001a, 635.

103 Mutch 2004.

104 Bhaskar [1979] 1998; Archer 1995.

105 Danermark et al. 2002.

106 Durham et al., 2013.

${ }^{107}$ Bhaskar [1979] 1998.

${ }^{108}$ Nash 2011, 461; Mehrotra 2010.

${ }^{109}$ New 2003, 65 c.f. Weedon 1997, 163.
} 
separate categories from the lived experiences of the people to whom they refer and be aimed primarily towards causal explanation, not prediction. Categories would be seen as abstractions and actors as their referents, occupying dynamic, non-deterministic structural positions that constrain or enable them, in concert or in conflict, in intersecting ways. It would reject the additive approach that places oppression as the sum total of multiple categories of discrimination in favour of an approach that understands these categories as mutually shaped by, and shaping, each other. ${ }^{110}$ Seeking links between the macro and the micro, ${ }^{111}$ it would acknowledge and attend to the fluid nature of intersections and categories as they impact identities and agency, but recognize that the social meanings and conditions attached to categories are structurally emergent and therefore, more durable over time. This conceptual framework thus offers the potential to answer Nash's call $^{112}$ to advance intersectional theory and research by enabling it to more effectively explain the nature of structures of domination, as well as how they are connected and replicate themselves.

\section{Conclusion}

Critical realism offers intersectional theory an alternative ontological framework that has the potential to remove it from the quagmire of a growing critique that has the potential to obscure and constrain its contribution. This article has helped to illustrate the manner in which the scope and explanatory power of intersectionality theory is limited by implicit philosophical assumptions stemming from roots in positivist and hermeneutic traditions. It argues that critical realism contains the conceptual tools necessary to augment intersectionality theory and rectify some of its problematic limitations. Building on existing feminist critiques of intersectionality, the foundations for a novel approach to intersectional complexity, one that takes critical realism as its predominant philosophical influence, has been proposed. This critical realist positional approach moves away from, on the one hand, inter- and intra-categorical conceptions of discrete and intersecting social categories, and on the other, the popular anti-categorical approaches that reject categories altogether. Instead, categories can be taken as abstract starting points with durable social meaning from which to explore broader structural inequalities as well as dynamic processes of positionality and agency. Using critical realist tools to develop intersectionality theory in this way would enable its advancement beyond discussions of identity and towards the original aims of the intersectional and realist projects of dismantling structures of social oppression, and promoting emancipation and human flourishing.

\footnotetext{
${ }^{110}$ see Yuval-Davis 2006; Walby et al. 2012.

${ }^{111}$ Mole 2012.

${ }^{112}$ Nash 2011.
} 


\section{Bibliography}

Acker, J. 2000. 'Revisiting Class: Thinking from Gender, Race and Organizations'. Social Politics 7(2): 192-214.

Acker, J. 2006. 'Inequality Regimes: Gender, Class, and Race in Organizations'. Gender \& Society 20: 441-464.

Ahmed, S. 2012. On Being Included: Racism and Diversity in Institutional Life. Durham and London: Duke University Press.

Anthias, F. 2001a. 'New Hybridities, Old Concepts: The Limits of “Culture"'. Ethnic and Racial Studies 24(4): 619-641.

Anthias, F. 2001b. 'The Material and The Symbolic in Theorizing Social Stratification: Issues of Gender, Ethnicity and Class'. British Journal of Sociology 52(3): 367-390.

Anthias, F. 2002. 'Beyond Feminism and Multiculturalism: Locating Difference and the Politics of Location'. Women's Studies International Forum 25(3): 275-286.

Anthias, F. 2006. 'Belongings in a Globalising and Unequal World: Rethinking Translocations'. In The Situated Politics of Belonging, eds N. Yuval-Davis, K. Kannabiran and U. Vieten. London: Sage.

Anthias, F. 2008. 'Thinking Through the Lens of Translocational Positionality: An Intersectionality Frame for Understanding Identity and Belonging'. Translocations: Migration and Social Change 4(1): 5-20. [online] Available at:

http://www.dcu.ie/imrstr/volume 4 issue $1 /$ Vol 4 Issue 1 Floya Anthias.pdf. Accessed 19 Jan 2013.

Anthias F., Yuval-Davis, N. 1992. Racialized Boundaries. London: Routledge.

Archer, M. 1995. Realist Social Theory: The Morphogenetic Approach. Cambridge: Cambridge University Press.

Archer, M. 2000. Being Human: The Problem of Agency. Cambridge: Cambridge University Press.

Bhaskar, R. [1975] 2008. A Realist Theory of Science. $2^{\text {nd }}$ Edition. London: Verso.

Bhaskar, R. [1979] 1998. The Possibility of Naturalism. $3^{\text {rd }}$ Edition. London: Routledge.

Bhaskar, R. [1993] 2008. Dialectic: The Pulse of Freedom. $2^{\text {nd }}$ Edition. London: Routledge.

Bordieu, P. 1977. Outline of a Theory of Practice. Cambridge: Cambridge University Press.

Bowleg, L. 2008. 'When Black + Lesbian + Woman $\neq$ Black Lesbian Woman: The Methodological Challenges of Qualitative and Quantitative Intersectionality Research'. Sex Roles 59(5-6): 312325.

Brown, T., Heggs, D. 2005. 'From Hermeneutics to Poststructuralism to Psychoanalysis'. In Research Methods in the Social Sciences, eds B. Somekh and C. Lewin. London: Sage.

Butler, J. 1990. Gender Trouble: Feminism and the Subversion of Identity. New York and London: Routledge.

Butler, J. 1998. 'Merely Cultural'. New Left Review I(277): 33-44.

Carbin, M., Edenheim, S. 2013. 'The Intersectional Turn in Feminist Theory: A Dream of a Common Language?'. European Journal of Women's Studies 20(3): 233-248.

Clegg, S. 2006. 'The Problem of Agency in Feminism: A Critical Realist Approach'. Gender and Education 18(3): 309-324.

Combahee River Collective. 1977. A Black Feminist Statement From The Combahee River Collective. [online] Available at: http://www.feministezine.com/feminist/modern/Black-FeministStatement.html. [Accessed 22 Jan 2013].

Cooper, F. R. 2005. 'Against Bipolar Black Masculinity: Intersectionality, Assimilation, Identity Performance, and Hierarchy'. U.C. Davis Law Review 39: 853-904. 
Crenshaw, K. 1989. 'Demarginalizing The Intersection Of Race And Sex: A Black Feminist Critique Of Antidiscrimination Doctrine, Feminist Theory And Antiracist Politics.' The University of Chicago Legal Forum: 139-167.

Cruickshank, J. 2003. 'Introduction'. In Critical Realism: The Difference it Makes, ed J. Cruickshank. London: Routledge.

Danermark, B., Ekström, M., Jakobsen, L., Karlsson, J. C. 2002. Explaining Society: Critical Realism in the Social Sciences. London and New York: Routledge.

Davis, A. 1981. Women, Race and Class. New York: Random House.

Davis, K. 2008. 'Intersectionality as Buzzword: A Sociology of Science Perspective on What Makes a Feminist Theory Successful'. Feminist Theory 9(1): 67-85.

Dhamoon, R.K. 2011. 'Considerations on Mainstreaming Intersectionality'. Political Research Quarterly 64(1): 230-243.

Durham, A., Cooper, B.C., Morris, S.M. 2013. 'The Stage Hip-Hop Feminism Built: A New Directions Essay'. Signs 38(3): 721-737.

Frankenberg, R. 1993. White Women, Race Matters: The Social Construction of Whiteness. Minneapolis: University of Minnesota Press.

Geerts, E., van der Tuin, I. 2013. 'From Intersectionality to Interference: Feminist OntoEpistemological Reflections on the Politics of Representation' Women's Studies International Forum 41(3): 171-178.

Giddens, A. 1979. Central Problems in Social Theory: Action, Structure and Contradiction in Social Analysis. Berkeley and Los Angeles: University of California Press.

Gunnarson, L. 2011. 'In Defence of The Category “Woman"'. Feminist Theory 12(1): 23-37.

Hancock, A. 2007. 'When Multiplication Doesn't Equal Quick Addition: Examining Intersectionality as a Research Paradigm'. Perspectives on Politics 5(1): 63-79.

Haraway, D. 1988. 'Situated Knowledges: The Science Question in Feminism and the Privilege of Partial Perspective'. Feminist Studies 14(3): 575-599.

Harding, S. 1991. Whose Science? Whose Knowledge? Thinking from Women's Lives. Milton Keynes: Open University Press.

Harding, S. 1986. 'The Instability of the Analytical Categories of Feminist Theory'. Signs 11(4): 645664.

Hill Collins, P. [1990] 2000. Black Feminist Thought. $2^{\text {nd }}$ Edition. New York, NY: Routledge. hooks, b. 1981. Ain't I a Woman: Black Women and Feminism. Boston, MA: South End Press.

Hurtado, A. 1989. 'Relating to Privilege: Seduction and Rejection in the Subordination of White Women and Women of Color'. Signs 14(4): 833-855.

Letherby, G. 2003. Feminist Research in Theory and Practice. Buckingham, Open University Press. Maier, M. 1997. 'Invisible Privilege: What White Men Don't See'. The Diversity Factor 5(4): 28-33.

McCall, L. 2005. 'The Complexity of Intersectionality'. Signs 30(3): 1771-1800.

Mclntosh, P. 1989. 'White Privilege: Unpacking the Invisible Knapsack'. Peace and Freedom July/August: 10-12.

McNay, L. 2000. Gender and Agency: Reconfiguring the Subject in Feminist and Social Theory. Cambridge: Polity.

Mole, K. 2012. 'Critical Realism and Entrepreneurship'. In Perspectives in Entrepreneurship: A Critical Approach ed K. Mole with M. Ram. Houndmills: Palgrave MacMillan.

Mutch, A. 2004. 'Constraints on the Internal Conversation: Margaret Archer and the Structural Shaping of Thought'. Journal for the Theory of Social Behaviour 34(4): 429-445.

Nash, J. 2008. 'Re-Thinking Intersectionality'. Feminist Review 89: 1-15. 
Nash, J. 2011. "Home Truths" on Intersectionality'. Yale Journal of Law and Feminism 23(1): 445470.

New, C. 2003. 'Feminism, Critical Realism and the Linguistic Turn'. In Critical Realism: The Difference it Makes, ed. J. Cruickshank. London: Routledge.

New, C. 1998. 'Realism, Deconstruction and the Feminist Standpoint'. Journal for the Theory of Social Behaviour 28(4): 349-372.

Oleksy, E. 2011. 'Intersectionality at the cross-roads'. Women's Studies International Forum 34(4): 263-270.

Porpora, D. 1998. 'Four Concepts of Social Structure'. In Critical Realism: Essential Readings eds M. Archer, R. Bhaskar, A. Collier, T. Lawson and A. Norrie. New York, NY: Routledge.

Prins, B. 2006. 'Narrative Accounts of Origins: A Blind Spot in the Intersectional Approach?' European Journal of Women's Studies 13(3): 277-290.

Walby, S., Armstrong, J., Strid, S. 2012. 'Intersectionality: Multiple Inequalities in Social Theory'. Sociology 46: 224-240.

Yuval-Davis, N. 2006. 'Intersectionality and Feminist Politics'. European Journal of Women's Studies 13(3): 193-209.

\section{Notes on contributors}

Angela Martinez Dy is a teaching associate at the University of Nottingham. Lee Martin lectures in Entrepreneurship and Creativity at University of Nottingham.

Susan Marlow is Professor of Entrepreneurship at University of Nottingham

Correspondence to Angela Martinez Dy, Nottingham University Business School, Jubilee Campus, Wollaton Road, Nottingham NG8 1BB, UK. Email: angela.dy@nottingham.ac.uk 
TABLE 1

EXTANT INTERSECTIONAL APPROACHES TO METHODOLOGICAL COMPLEXITY

\begin{tabular}{|l|l|l|l|}
\hline $\begin{array}{l}\text { Approach to } \\
\text { Complexity }\end{array}$ & $\begin{array}{l}\text { Inter-categorical } \\
\text { (Categorical) }\end{array}$ & Intra-categorical & Anti-categorical \\
\hline $\begin{array}{l}\text { Approach to } \\
\text { Categories }\end{array}$ & Provisionally adopt & $\begin{array}{l}\text { Categories inadequate, } \\
\text { but identify complexity }\end{array}$ & Deconstruct and reject \\
\hline $\begin{array}{l}\text { Predominant } \\
\text { Philosophical Influence }\end{array}$ & Post-positivist & Positivist-Hermeneutic & $\begin{array}{l}\text { Hermeneutic } \\
\text { (Discursive approach) }\end{array}$ \\
\hline $\begin{array}{l}\text { Problematic } \\
\text { Assumptions }\end{array}$ & $\begin{array}{l}\text { Categories fixed, can } \\
\text { be analyzed discretely }\end{array}$ & $\begin{array}{l}\text { Intersections fixed, } \\
\text { experience }=\text { theory }\end{array}$ & $\begin{array}{l}\text { Categories fictional } \\
\text { and thus, irrelevant }\end{array}$ \\
\hline Problematic Outcomes & $\begin{array}{l}\text { Additive approach, } \\
\text { mathematical tropes }\end{array}$ & Epistemic fallacy & $\begin{array}{l}\text { Focus limited to } \\
\text { 'identity' or 'discourse' }\end{array}$ \\
\hline
\end{tabular}


TABLE 2

LIMITATIONS, GAPS, AND THE CONCEPTUAL POSSIBILITIES OF CRITICAL REALISM

\begin{tabular}{|l|l|}
\hline Intersectionality Theoretical Limitations and Gaps & Critical Realism Conceptual Tool \\
\hline $\begin{array}{l}\text { Tendency to collapse theory and experience (Nash } \\
\text { 2008) }\end{array}$ & Depth ontology (Bhaskar 2008) \\
\hline $\begin{array}{l}\text { Focus on individuals to the detriment of structural } \\
\text { analysis (Yuval-Davis 2006); structure under- } \\
\text { theorized or limited to mathematical tropes } \\
\text { (Mehrotra 2011) }\end{array}$ & $\begin{array}{l}\text { Morphogenetic approach (Archer } \\
1995 / 2000)\end{array}$ \\
\hline $\begin{array}{l}\text { Push to deconstruct social categories and dismiss } \\
\text { them as irrelevant (McCall 2005) }\end{array}$ & $\begin{array}{l}\text { Categories as abstractions with real } \\
\text { economic (Gunnarsson 2011) }\end{array}$ \\
\hline $\begin{array}{l}\text { Concrete universals (Bhaskar [1993] 2008) } \\
\text { Lack of theory on agency (Nash 2008) }\end{array}$ & $\begin{array}{l}\text { Morphogenetic approach, three-stage } \\
\text { model (Archer [1995] 2000) }\end{array}$ \\
\hline $\begin{array}{l}1975] \text { 2008, [1993] 2008) } \\
\text { Lansfactuality and absence (Bhaskar }\end{array}$ \\
\hline
\end{tabular}


TABLE 3

POSITIONAL APPROACH TO METHODOLOGICAL COMPLEXITY IN INTERSECTIONALITY

\begin{tabular}{|c|c|}
\hline Approach to Complexity & Positional \\
\hline Approach to Categories & $\begin{array}{l}\text { Use as starting point to analyze broader } \\
\text { social locations and processes. }\end{array}$ \\
\hline $\begin{array}{l}\text { Predominant } \\
\text { Philosophical Influence }\end{array}$ & Critical Realist \\
\hline Key Assumptions & $\begin{array}{l}\text { Depth ontology, transfactuality, and } \\
\text { morphogenetic approach to structure, } \\
\text { culture, and agency. Concrete } \\
\text { universals. }\end{array}$ \\
\hline Key Outcomes & $\begin{array}{l}\text { Structure }=\text { durable relationships that } \\
\text { position, constrain and/or enable. Social } \\
\text { positioning as a continuous process, } \\
\text { negotiated by agency. Marginality not a } \\
\text { monolith. Nuanced experiences of } \\
\text { privilege and oppression. }\end{array}$ \\
\hline
\end{tabular}


TABLE 4

\section{CRITICAL REALIST INTERSECTIONAL ONTOLOGY}

\begin{tabular}{|l|l|}
\hline Real & $\begin{array}{l}\text { Real generative mechanisms emerge from intersecting structures of } \\
\text { domination that serve to position individuals and groups within social } \\
\text { hierarchies. } \\
\text { These complex and dynamic mechanisms privilege or disadvantage (enable } \\
\text { or constrain) agents in relation to social mobility and material, political, } \\
\text { social, cultural, and economic resources. }\end{array}$ \\
\hline Actual & $\begin{array}{l}\text { Enablement or constraint on the basis of positionality impacts people's lives } \\
- \text { in particular, by offering or limiting opportunities and choices, and affecting } \\
\text { how they are perceived and treated by institutions, groups and individuals. }\end{array}$ \\
\hline Empirical & $\begin{array}{l}\text { Via their tendencies, privileges and disadvantages are recognized, } \\
\text { acknowledged, and understood by individual agents, others, institutions. } \\
\text { They may (to some degree) be measurable or quantifiable. They may (or may } \\
\text { not) be taken into account and considered in the exercise of agency. }\end{array}$ \\
\hline
\end{tabular}

